\title{
Sri Lankan Beverage Consumers' Purchase Intention
}

\author{
H.M.A. Herath ${ }^{1} \&$ L.H.D. Fernando ${ }^{2}$ \\ ${ }^{1,2}$ Department of Business Management \\ Faculty of Business Studies \& Finance \\ Wayamba University of Sri Lanka \\ Kuliyapitiya \\ SRI LANKA \\ herathhma@wyb.ac.lk르. hirushafernando4@gmail.com ${ }^{2}$
}

\begin{abstract}
Generally, it is accepted that the consumption of soft drinks is hazardous for human health. There are heavy involvements by some of the health authorities and the government to discourage the consumption of soft drinks specially by student community and encourage them to use indigenous options. Nevertheless, the soft drink market in Sri Lanka is huge and some popular brands have shared considerable market shares among themselves. Since there is a need for influencing the demand and consumption, it is inevitable to understand the behavior patterns of market variables. Accordingly, this study focused the relationship of few variables with ordinary consumer's preference for buying soft drinks. The research model of the study was included four independent variables, education, status, health concerns and experience. The research model was tested in Gampaha District in Sri Lanka where there is the second highest population and largest student population. Data was collected from 300 randomly selected sample of soft drink consumers by using standard, structured measurements. The result of the study confirmed that education level and health concern negatively and perceived social status and buying experience positively related to the Sri Lankan beverage consumers' purchase intention.
\end{abstract}

Keywords: Purchase Intention, Beverage Consumption, Consumer Preference, Soft Drinks, Sri Lanka

\section{INTRODUCTION}

Consumer buying behavior refers to the multi-step decision making process people engage in and the actions they take to satisfy their needs and wants in the market place. The buying behavior is results of motives. In buying process various motives may conflict with one another. A motive is a stimulated need that an individual seeks to satisfy. The decision processes and the final act of the consumer associates with evaluating, buying consuming, and discarding products. Consumer purchase intention is central to the marketing of a product. Moreover, marketers always try to address the consumers' motives, drives by using 
promotional strategies including heavy advertising campaigns to influence consumers' behavior favorably towards their products.

The soft drink market in the world is one of the heaviest markets while it is expected a further growth. The existing evidences prove that the soft drinks consumption is increasing worldwide. In comparison with the year 2009, the global soft drinks consumption increased by $4 \%$ in 2010 with a per capita consumption of 81 liters. The highest growth trend in market in year 2010 was estimated in Asian countries, including world largest markets, India and China reporting growth rates of $16 \%$ and 14 $\%$ respectively News System (2011).

As per Statista 2014, the revenue in the soft drinks segment will amount to US\$667,384m in 2020. Moreover, the market is expected to grow annually by $6.5 \%$ (CAGR 20202025). (The compound annual growth rate (CAGR) is the annualized average rate of revenue growth between two given years, assuming growth takes place at an exponentially compounded rate). In global comparison, most revenue will be generated in the United States (US\$ 200,290m in 2020). In relation to total population figures, per person revenues of US\$ 89.67 will be generated in 2020. The average per capita consumption will stand at $45.2 \mathrm{~L}$ in 2020.

The changing income levels and lifestyles of Sri Lankans are likely to shift their consumption patterns to higher level of consuming soft drinks. Sri Lanka's total soft drink market is worth around US\$ 80 million
(Niroshan et al, 2008). The large scale companies dominate the beverage market in Sri Lanka.

However, almost all of the beverages are sugar-sweetened and include artificial flavours and preservatives. Consumption of such beverages has detrimental effects on the general health of the people. The reviews on the relationship between the use of sugar-sweetened beverages and possibility of weight gain provide positive strong evidences. Particularly sugar-sweetened carbonated drinks well promotes weight gain and obesity among people (Malik, Schulze \& Hu, 2006). Moreover, the consumption of sugarsweetened soft drinks is strongly associated with dental erosion (Levine, Nugent and Rudolf, 2007; Sanhouri and Hashim, 2007). Accordingly, it is obvious now over use of sweetened beverages create poor health among consumers.

\subsection{Research Problem}

The problem of this study was defined in the perspective of the Sri Lankan beverage consumers' health condition which may likely to endangered due to heavy consumption of sweetened beverages. There are evidences to indicate that soft drink consumption is growing in Asian countries (Taylor, Satija, Khurana, 2011).

In Sri Lanka, suger-sweetned beverage consumption has been growing at significant rate. From 2009 to 2013, annual average per capita GDP growth was $6.5 \%$, while annual average growth rate of 
beverage consumption was $7.5 \%$ (Euromonitor International, 2014).

According to Euromonitor International, 2013, Sri Lankans has consemed about 78 million litres of carbonated beverages in 2012. As estimated average prices, the ratio of total sales over the volume was $124 \mathrm{mn}$ LKR for Carbonated beverages within the period of 20142017. The forecasted sales volume for 2017 was 94 million liters. Average price increase for beverages in Sri Lankan market is of $12 \%$ over the period of 2014- 2017. However, as per the Sri Lanka Department of Census and Statistics, actual average price increase between January 2014 and June 2017 is $17 \%$.

In Sri Lankan context, overweight and obesity of people is at a low 0.5 $\%$ in children under 5 years of age. But it increases to 5-6\% by the Year 10 in school age. Among Sri Lankan adult males, overweight and obesity is $24.5 \%$ and $34.4 \%$ respectively while adult females report the overweight as $19.6 \%$ and obesity $30.4 \%$, in 2010. In addition, diabetes level in the same group remains $9.7 \%$. Both diabetes and cardiovascular diseases, are responsible for significant morbidity and mortality in Sri Lanka. The current health expenditure on all NCDs amounts to Rs 91.6 billion, $35.2 \%$ of the total current health expenditure (Health Economics Cell, 2013-2016).

Although the available statistics show a possibility of a severe health problem among beverage consumers, there is a paucity of the empirical studies for studying the Sri Lankan beverage consumers' attitudes and buying behavior patterns. Nilantha and Lilani, (2012) studied the soft drink consumption in Sri Lankan adolescents and found that nearly 82 $\%$ consumed sugar-sweetened soft drinks once a week and out of those, $2 \%$ were consuming daily. However, due to paucity of empirical evidences in the field, the present researchers are in a difficulty to go for testing complex explanatory research models on beverage consumers' attitudes and behavioral patterns and have to conduct the preliminary explorations for accumulating basic information in the field. However, it is obvious that basic explorations which will open more avenues for advanced studies in the field are essential.

\subsection{The Conceptualization}

Consumer purchasing behavior refers to the behavior of final consumers in purchasing a product (Kotler et al, 2012). Yang, Hung \& Feng (2011), studied the influence of demographic variables like age, education, social class, experience and gender on consumer's purchase intention in fashion clothing industry. Paul, Turn \& Alan (1996) revealed that the young consumers who have less buying experience, trust and rely more on the branded products than their older counterparts. However, since such primary studies are lacking in the field of beverage consumers' purchase intention, the focus of this study was limited only for finding the relationships between four independent variables and Sri Lankan beverage consumers' purchase intention. Many studies have been conducted on consumers purchase intention instead of studying the real 
consumer behavior since researchers indicate that the consumers' purchase intention reflects their real buying behavior. The study selected Education Level, Health Concern, Social Status and Buying Experience as independent variables to investigate their relationships with Sri Lankan beverage consumers' purchase intention

\subsection{Research Question}

By taking the lack of empirical evidences in the field into consideration and on the basis of the available findings in other fields, the study found the answer for the research question "Does the relationships exist of the educational level, health concern, social status and buying experience of Sri Lankan beverage consumers with their purchase intention of beverages.

\subsection{Research Objectives}

Based on the conceptualization that may exist in the real beverage market, following research objectives were formulated.

- To investigate the relationship between education level and purchase intention of Sri Lankan beverage consumers' purchase intention.

- To investigate the relationship between health concern of the consumer and purchase intention of Sri Lankan beverage consumers' purchase intention.

- To investigate the relationship social status of the consumer and purchase intention of
Sri Lankan beverage consumers' purchase intention.

- To investigate the relationship between buying experience of consumer and purchase intention of Sri Lankan beverage consumers' purchase intention.

\subsection{Hypotheses}

To achieve the objectives of the study, statistically testable four hypotheses were formulated. Among hypotheses, education level and health concern were hypothesized negative relationships with purchase intention while positive relationships were hypothesized between social status, buying experience and purchase intention of Sri Lankan beverage consumers.

\section{METHODS}

A deductive approach was used for the study where the researcher deduced four testable hypotheses from reviewing literature. The study used quantitative positivistic approach while the sample of 300 beverage consumers were randomly selected from the 13 divisional secretariats of Gampaha district in Sri Lanka. The majority of the respondents $(65.0 \%)$ to the study were female, indicating that more females are consuming soft drinks in Gampaha as compared to males (35.0\%). Since the 61 respondents are above 60 years of age represented $30.5 \%$. The majority of soft drink consumers are mainly elder people. By considering educational level of the customers, the majority of the respondents (58) were below ordinary level holders, only (8.0) \% of the 
respondents are bachelor's degree holders. The data obtained from the questionnaire revealed that majority of the customers $(63 \%)$ buying soft drinks are married.

The sample was surveyed by selfadministering a standard, structured questionnaire for collecting data. The questionnaires were directly distributed to the beverage consumers and data was get collected on the spot. The questionnaire composed of two major sections one for gathering the demographic information of the sample members and other part for collecting data on the independent and dependent variables. The time horizon of the study was cross sectional and the study setting was non-contrive.

\subsection{Testing Assumptions}

Since the study was correlational, a single multivariate assumption, normality of the variables were tested. As per the values for skewness and kurtosis given in the table 1 . Proved that the no variable is deviated from the normality assumption.

Table 1. Test of Normality

\begin{tabular}{|l|l|l|}
\hline Variables & Kurtusis & Skewness \\
\cline { 2 - 3 } & Statistic & Statistic \\
\hline $\begin{array}{l}\text { Consumer } \\
\text { purchase } \\
\text { intention }\end{array}$ & 0.24 & -0.755 \\
\hline Education & -0.531 & 0.006 \\
\hline $\begin{array}{l}\text { Health } \\
\text { concern }\end{array}$ & -0.734 & 0.244 \\
\hline $\begin{array}{l}\text { Social } \\
\text { status }\end{array}$ & -.581 & 0.084 \\
\hline Experience & -1.019 & 1.431 \\
\hline
\end{tabular}

\section{RESULTS}

To answer the research questions, and achieve the objectives formulated, the Pearson correlation coefficients were estimated for testing four hypotheses.

The Pearson correlation coefficients are presented in the table 2.

\section{Table 2. Results of Correlation} Analysis

\begin{tabular}{|l|l|l|}
\hline Factors & $\begin{array}{l}\text { Consumers' } \\
\text { purchase } \\
\text { intention }\end{array}$ & Sig. \\
\hline $\begin{array}{l}\text { Education } \\
\text { level }\end{array}$ & -0.664 & 0.000 \\
\hline $\begin{array}{l}\text { Health } \\
\text { concern }\end{array}$ & -0.314 & 0.003 \\
\hline $\begin{array}{l}\text { Social status } \\
\text { Buying } \\
\text { experience }\end{array}$ & 0.497 & 0.000 \\
\hline
\end{tabular}

As per the table 2., the P-value for educational level reported as 0.000 while the correlation coefficient remains -0.664 . It proves that there is a significant negative relationship between educational level and purchase behavior. Similarly, the negative relationship hypothesized in the second hypothesis can also be accepted under $95 \%$ of significant level with a $\mathrm{P}$ value less than .005 . The third hypothesis was formulated as significant positive relationship between social status and purchase intention which denotes .497 correlation coefficient with a $\mathrm{P}$ value equals 000 and can be accepted. The last hypothesis proved positive significant relationship between buying experience and purchase 
intention with .561 Pearson correlation coefficient and $\mathrm{P}$ value is significant at $99 \%$. Accordingly, all the four hypotheses formulated in this study were accepted.

\section{CONCLUSION}

The results of the study concluded that the education level and health concern significantly and negatively correlated while social status and buying experience positively and significantly correlated with Sri Lankan beverage consumers' purchase intention. The result also implies that the people should be educated and made aware of possible health hazardous of beverage consumption if people are needed to be discouraged form beverage consumption. When the perceived social status getting improved, the usage of beverage consumption goes up. However, it is dubious whether the perceived social status forces the consumers to increase the usage or whether they perceive that the purchasing and using beverages represents the higher social status, since this is not a causal study. More studies are essential for finding the causality between possible independent variables and purchase intention. The higher the buying experience of beverages higher the beverage consumption of Sri Lankan consumers. It implies that the children and school students should be prevented from frequently experiencing the purchase of beverages. It is recommended the non-availability of sweetened beverages in school canteens and in shops nearby the places where children are available. Also as an optional solution, fresh fruit drinks and other indigenous healthy drinks can make available.

For the future researchers there are more avenues opened for extending into other variable doing causal studies by covering the total beverage market in Sri Lanka.

\section{REFERENCES}

Euromonitor International (2013). Markets of the future in Sri Lanka.

Euromonitor International (2014). Markets of the future in Sri Lanka.

Health Economics Cell, (2013. 2016). Ministry of Health; Nutrition and Indigenous Medicine. Sri Lanka National Health Accounts

Levine RS, Nugent ZJ, Rudolf MC, (2007) Dietary patterns, tooth brushing habits and caries experience of school children in west Yorkshire, England. Community Dent Health 24, 82 87. 7. El Karim IA,

Malik VS, Schulze MB \& Hu FB (2006) Intake of sugar-sweetened beverages and weight gain: a systematic review. Am J Clin Nutr 84, 274-288.

News System (2011). Global soft drink consumption increases in 2010. http://www.ceepackaging.com/20 11/08/09/globalsoft-drinksconsumption (accessed December 2011). 
Nilantha R., Lilani E. (2012). Soft drink consumption in Sri Lankan adolescents April 2012 Public Health Nutrition 15(8):13337 Follow Journal. DOI: $10.1017 / S 13689800120010$ 61

Niroshan, M.G.A. Dissanayake, S. N. \& Bernard, D.T.K. (2008). Consumer Behavior Consumer Preferences of Ready to Drink Fruit Beverages in Sri Lanka Beverage Market. Second Annual Research Forum of SAEA.

Kotler, P. \& Keller, K. (2012). Marketing Management. 14th edition. Delhi: Pearson Education.
Sanhouri N.M., Hashim N.T., (2007) Dental erosion among 12-14year-old school children in Khartoum: a pilot study. Community Dent Health 24, 176180.

Taylor F.C., Satija A., Khurana S. (2011) Pepsi and Coca Cola in Delhi, India: availability, price and sales. Public Health Nutr 14, 653-660. 